\title{
Aplikasi Asuhan Keperawatan Jiwa Pada Tn. A Dengan Masalah Isolasi Sosial Di Yayasan Pemenang Jiwa Sumatera
}

\author{
Andika Rahmat Harefa
}

$\underline{\text { Andikarahmat444harefa@gmail.com }}$

\author{
BAB 1 \\ PENDAHULUAN
}

\subsection{Latar Belakang}

Skizofrenia merupakan penyakit kronis, parah, dan melumpuhkan, gangguan otak yang di tandai dengan pikiran kacau, waham, delusi, halusinasi, dan perilaku aneh atau katatonik (Pardede \& Laia, 2020). Menurut WHO (2019, dalam Pardede 2020, Skizofrenia merupakan gangguan mental berat dan kronis yang menyerang 20 juta orang di seluruh dunia. Hasil Riskesdas (2018) didapatkan estimasi prevalensi orang yang pernah menderita skizofrenia di Indonesia sebesar 1,8 per 1000 penduduk. Privalensi ganguan jiwa di Indonesia urutan pertama adalah Bali 11,1\% dan nomor dua disusul Yogyakarta 10,4\%, NTB 9,6\%, Sumatera Barat 9,1\%, Sulawesi Selatan 8,8\%, Daerah Istimewa Aceh 8,7\%, Jawa Tengah 8,7\%, Sulawesi Tengah 8,2\%, Sumatera Selatan 8\%, Kalimantan Barat 7,9\%. Sedangkan Sumatera Utara berada pada posisi ke 21 dengan privalensi 6,3\% (Kemenkes,2019). Gejala positif dari skizofrenia termasuk isolasi social (Pardede, Hamid \& Putri, 2020)

Isolasi sosial merupakan keadaan dimana individu mengalami penurunan atau bahkan sama sekali tidak mampu berinteraksi dengan orang lain disekitarnya. Klien mungkin merasa ditolak, tidak diterima, kesepian, dan tidak mampu membina hubungan yang berarti dengan orang lain Interaksi sosial merupakan hubungan sosial yang dinamis, yang menyangkut hubungan antara individu, antara individu dengan kelompok, maupun antara kelompok yang satu dengan kelompok yang lain yang saling mempengaruhi, mengubah atau memperbaiki 
perilaku individu lainnya atau sebaliknya di dalam masyarakat yang mengakibatkan terjadinya perubahan dalam masyarakat ataupun proses sosial, hal ini sesuai dengan hasil penelitian terkait hubungan antara dukungan keluarga dengan keberfungsian sosial pada pasien skizofrenia pasca perawatan di rumah sakit. Sumbangan efektif dukungan keluarga terhadap keberfungsian sosial pada pasien skizofrenia pasca perawatan di rumah sakit sebesar 69,9\% dan faktor-faktor lain memberi pengaruh sebesar 30,1 \% (Quardona \& Agustina 2018).

Pasien dengan masalah isolasi sosial mengalami penurunan fungsi kognitif, sehingga disamping program keterampilan sosial yang dilatih pada pasien, pasien juga membutuhkan suport sistem baik dari dalam maupun dari luar keluarga. Keluarga atau anggota keluarga harus dapat memanfaatkan sumber fasilitas kesehatan yang ada disekitar, apabila mengalami gangguan atau masalah yang berkaitan dengan penyakit. Keluarga dapat berkonsultasi atau meminta bantuan tenaga keperawatan dalam rangka memecahkan problem yang dialami anggota keluarga, sehingga keluarga dapat bebas dari segala macam penyakit (Pardede 2018). Pasien yang mengalami masalah isolasi social harus diberikan terapi non farmakologis agar pasien mampu berinteraksi dengan orang lain seperti, terapi generalis (Strategi pelaksanaan 1-4) yang diberikan melalui asuhan keperawatan jiwa.

Pemberian asuhan keperawatan jiwa pada pasien dengan masalah isolasi sosial berfokus pada membina hubungan saling percaya, memberi kegiatan sesuai dengan kemampuan pasien, meningkatka kontak dengan orang lain, mendorong pasien mengungkapkan pikiran dan perasaan serta membantu melihat prestasi, kemampuan dan harapan pasien. Survei awal yang dilakukan untuk pemberian asuhan keperawatan pada pasien skizofrenia ini dilakukan di Yayasan pemenang jiwa Sumatera dengan jumlah pasien 70 orang tetapi yang menjadi subjek adalah 1 orang dengan pasien isolasi sosial pada Tn. A. 


\subsection{Rumusan Masalah}

Berdasarkan masalah yang telah dipaparkan pada latar belakang maka rumusan masalah dalam masalah askep ini yaitu: asuhan keperawatan jiwa pada Tn. A dengan gangguan isolasi sosial di Yayasan pemenang jiwa sumatera.

\subsection{Tujuan}

1.3.1 Tujuan Umum

Mahasiswa mampu memberikan asuhan keperawatan jiwa kepada Tn.A dengan gangguan isolasi sosial

\subsubsection{Tujuan Khusus}

1. Mahasiswa mampu memahami Pengertian, etiologi, tanda dan gejala, klasifikasi, dan penatalaksanaan dan gangguan isolasi sosial

2. Mahasiswa mampu melakukan pengkajian pada Tn.A dengan gangguan isolasi sosial

3. Mahasiswa mampu menegakkan diagnosa keperawatan yang ada pada Tn.A dengan gangguan isolasi sosial

4. Mahasiswa menetapkan perencanaan keperawatan pada Tn.A dengan gangguan isolasi sosial

5. Mahasiswa melakukan implementasi keperawatan pada Tn.A dengan gangguan isolasi sosial

6. Mahasiswa mengevaluasi hasil asuhan keperawatan pada Tn.A dengan gangguan isolasi sosial 


\section{BAB 2 \\ TINJAUAN PUSTAKA}

\subsection{Konsep Isolasi Sosial}

\subsubsection{Pengertian Isolasi Sosial}

Isolasi sosial merupakan kondisi kesendirian yang di alami oleh individu dan dipersepsikan disebabkan orang lain dan sebagai kondisi yang negatif dan mengancam (Townsend, 2010). Kondisi isolasi sosial seseorang merupakan ketidakmampuan klien dalam mengungkapkan perasaan klien yang dapat menimbulkan klien mengungkapkan perasaan klien dengan kekerasan.Perilaku kekerasan merupakan respon destruktif individu terhadap stresor (Stuart, 2013).

Isolasi sosial merupakan keadaan dimana seseorang individu mengalami perilaku menarik diri, serta penurunan atau bahkan sama sekali tidak mampu berinteraksi dengan orang lain, terutama untuk mengungkapkan dan mengonfirmasi perasaan negatif dan positif yang dialaminya.

Setiap individu memiliki potensi untuk terlibat dalam hubungan sosial, pada berbagai tingkat hubungan, yaitu hubungan intim yang biasa hingga ketergantungan. Keintiman pada tingkat ketergantungan, dibutuhkan individu dalam menghadapi dan mengatasi kebutuhan dalam kehidupan sehari-hari. Individu tidak mampu memenuhi kebutuhannya tanpa adanya hubungan dengan lingkungan sosial. Maka dari itu hubungan interpersonal perlu dibina oleh setiap individu. Namun, hal tersebut akan sulit dilakukan bagi individu yang memiliki gangguan isolasi sosial (Sutejo, 2018).

\subsubsection{Etiologi}

Peyebab dari isolasi sosial yaitu peranan negatif tentang diri sendiri, hilang kepercayaan diri, merasa gagal mencapai keinginan, yang ditandai dengan adanya perasaan malu terhadap diri sendiri, rasa 
bersalah terhadap diri sendiri, gangguan hubungan sosial, merendahkan martabat, percaya diri kurang dan juga cepat mencederai diri (Muhith, 2015)

1. Faktor Predisposisi Beberapa faktor predispoisi (pendukung) terjadi gangguan hubungan yaitu : Faktor Perkembangan. Kemampuan membina hubungan yang sehat tergantung dari pengalaman selama proses tumbuh kembang. Setiap tahap tumbuh kembang memiliki tugas yang harus dilalui individu dengan sukses, karena apabila tugas perkembangan ini tidak dapat dipenuhi akan menghambat masa perkembangan selanjutnya. Kurangnya stimulasi, kasih sayang, perhatian, dan kehangatan dari orang tua pengasuh akan memberikan rasa tidak aman yang dapat menghambat terbentuknya rasa tidak percaya

a. Faktor Biologis, genetik merupakan salah satu faktor pendukung gangguan jiwa. Kelainan struktur otak seperti atrofi, pembesaran vetrikel, penurunan berat dan volume otak serta perubahan limbik diduga dapat menyebabkan skizofrenia

b. Faktor Sosial Budaya, faktor sosial budaya dapat menjadi faktor pendukung terjadinya gangguan dalam membina hubungan dengan orang lain, misalnya anggota keluarga yang tidak produktif diasingkan dari orang lain (Lingkungan sosial) (Muhith, 2015)

c. faktor Lain

d. Faktor Genetik dianggap mempunyai transmin gangguan efektif melalui riwayat keluarga dan keturunan.

\section{Stresor Presipitasi}

a. Stresor Sosial Budaya, stresor sosial budaya dapat menyebabkan terjadinya gangguan dalam membina hubungan dengan orang lain. Misalnya anggota keluarga yang labil yang dirawat dirumah sakit (Muhith, 2015) 
b. Stresor Psikologis, tingkat kecemasan yang berat akan menyebabkan menurunnya kemampuan individu untuk berhubungan dengan orang lain. Interaksi kecemasan yang ekstrem dan memanjang disertai terbatasnya kemampuan individu untuk mengatasi masalah diyakini untuk menimbulkan berbagai masalah gangguan hubungan (Muhith, 2015)

Rentang respon

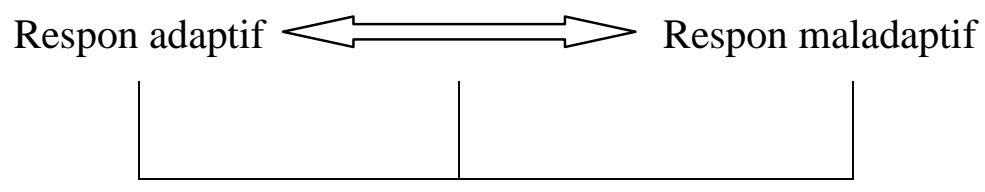

$\begin{array}{lll}\text { Menyendiri } & \text { Kesendirian } & \text { Manipulasi } \\ \text { Otonomi } & \text { Mengisolasi diri } & \text { Impulsif } \\ \text { Kebersamaan } & \text { Ketergantungan } & \text { Narkisisme }\end{array}$

1. Respon adaptif

Respon yang masih dapat diterima oleh norma norma sosial dan kebudayaan secara umum serta masih dalam batas normal dalam menyelesaikan masalah. Menyendiri : respon yang dibutuhkan seseorang untk merenungkan apa individu sehingga tidak dapat membina hubungan sosial secara mendalam. Curiga : Seseorang gagal mengembangkan rasa percaya terhadap orang lain (Iyus \& sutini, 2014)

2. Tanda dan Gejala
a. Gejala Subjektif
b. Klien menceritakan perasaan kesepian atau ditolak oleh orang lain
c. Klien merasa tidak aman berada dengan orang lain.
d. Tidak merawat diri dan tidak memperhatikan kebersihan diri
e. Mengisolasi diri
f. Tidak atau kurang sadar terhadap lingkungan sekitarnya 
g. Masukan makanan dan minuman terganggu

h. Retensi urin dan feses

i. Aktivitas menurun

j. Kurang Energi

k. Rendah diri (Iyus \& sutini, 2014)

3. Komplikasi

Klien dengan isolasi sosial semakin tenggelam dalam perjalanan dan tingkah laku masa lalu primitif antara lain pembicaraan yang autistik dan tingkah laku yang tidak sesuai dengan kenyataan sehingga berakibat lanjut menjadi resiko gangguan sensori persepsi, hausinasi, mencederai diri, orang lain, serta lingkungan dan penurunan aktivitas, sehingga dapat menyebakan defisit perawatan diri (Duden, 2013)

4. Mekanisme Koping

Mekanisme koping digunakan klien sebagai usaha mengatasi mengatasi kecemasan yang merupakan suatu kesepian nyata yang mengancam dirinya.

Kecemasan koping yang sering digunakan adalah regrasi, represi dan Isolasi. Sedangkan contoh sumber koping yang dapat digunakan misalnya keterlibatan dalam hubungan yang luas dalam keluarga dan teman, hubungan dengan hewan periharaan menggunakan kreatifitas untuk mengekspresikan stress interpersonal seperti kesenian musik atau tulisan (Duden, 2013).

\subsection{Penatalaksanaan}

Terapi pada gangguan jiwa skizofrenia dewasa ini sudah dikembnagkan sehingga penderita tidak mengalami diskriminasi bahkan metodenya lebih manusiawi dari pada masa sebelumnya. Terapi yang dimaksud meliputi :

\subsubsection{Psikofarmaka}

Berbagai jenis obat psikofarmaka yang beredar dipasaran yang hanya diperoleh dengan resep dokter, dapat dibagi dalam 2 golongan yaitu 
golongan generasi pertama (typical) dan golongan kedua (atypical). Obat yang termasuk golongan generasi pertama misalnya chlorpromazine HCL (psikotropik untuk menstabilkan senyawa otak), dan Haloperidol (mengobati kondisi gugup). Obat yang termasuk generasi kedua misalnya, Risperidone (untuk ansietas), Aripiprazole (untuk antipsikotik). (Wandono, 2017)

\subsubsection{Psikoterapi}

Terapi kerja baik sekali untuk mendorong penderita bergaul lagi dengan orang lain, penderita lain, perawat dan dokter, maksudnya supaya ia tidak mengasingkan diri lagi karena bila ia menarik diri ia dapat membentuk kebiasaan yang kurang baik. Dianjurkan untuk mengadakan permainan atau latihan bersama. (Wandono, 2017)

\subsection{Konsep Asuhan Keperawatan Jiwa}

\subsubsection{Pengkajian Keperawatan}

Pengkajian adalah sebagai dasar utama dari proses keperawatan. Tahap pengkajian terdiri dari pengumpulan data dan perumusan masalah pasien. Data yang dikumpulkan melalui data biologis, psikologis, sosial dan spiritual (Saputri \& Mar'atus, 2021)

\subsubsection{Analisa Data}

Analisa Data Dengan melihat data subyektif dan objektif dapat menentukan permasalahan yang dihadapi pasien. Dan dengan memperhatikan pohon masalah dapat diketahui penyebab, affeck dari masalah tersebut. Dari 12 hasil analisa data inilah dapat ditentukan diagnosa keperawatan (Hasannah, 2019).

\subsubsection{Diagnosa Keperawatan}

Pada Teori Isolasi Sosial (NANDA, 2015-2017), diagnosa keperawatan yang muncul sebanyak 2 diagnosa keperawatan yang meliputi:

1. Isolasi sosial : menarik diri

2. Harga diri rendah : gangguan konsep diri 


\subsubsection{Intervensi Keperawatan}

Intervensi pada pasien dengan Harga diri rendah dapat dilakukan dengan pemberian teknik mengontrol perilaku kekerasan dengan pemberian SP I cara fisik yaitu relaksasi tarik nafas dalam serta penyaluran energi, SP II dengan pemberian obat, SP III verbal atau social, SP IV spiritual. Intervensi tersebut dilakukan kepada pasien lalu pasien diberikan jadwal kegiatan sehari dalam upaya mengevaluasi kemampuan pasien (Hasannah, 2019).

\subsubsection{Implementasi Keperawatan}

Implementasi adalah tahapan ketika perawat mengaplikasikan ke dalam bentuk intervensi keperawatan guna membantu pasien mencapai tujuan yang telah di tetapkan. Kemampuan yang harus dimiliki oleh perawat pada tahap implementasi adalah kemampuan komunikasi yang efektif, kemampuan utnuk menciptakan saling percaya dan saling membantu, kemampuan melakukan teknik, psikomotor, kemampuan melakukan observasi sistemis, kemampuan memberikan pendidikan kesehatan, kemampuan advokasi dan kemampuan evaluasi (Anggit, 2021).

\subsubsection{Evaluasi Keperawatan}

Evaluasi Keperawatan merupakan proses yang berkelanjutan untuk menilai efek dari tindakan keperawatan pada pasien. Evaluasi dilakukan dengan pendekatan SOAP sebagai berikut, S : Respon subjektif pasien terhadap tindakan keperawatan yang telah dilaksanakan, 0 : Respon objektif pasien terhadap tindakan keperawatan yang telah dilaksanakan, A:Analisis terhadap data subjektif dan objektif untuk menyimpulkan apakah masalah masih tetap ada, muncul masalah baru, atau ada data yang kontradiksi terhadap masalah yang ada, dan P: Tindak lanjut berdasarkan hasil analisis respon pasien rencana tindak lanjut dapat berupa hal rencana dilanjutkan (jika masalah tidak berubah) atau rencana dimodifikasi (jika masalah tetap, sudah dilaksanakan semua tindakan terapi hasil belum memuasakan) (Anggit, 2021). 


\section{BAB 3 \\ TINJAUAN KASUS}

\subsection{Identitas Pasien}

$\begin{array}{ll}\text { Inisial } & : \text { Tn. A } \\ \text { Jenis kelamin } & : \text { Laki-laki } \\ \text { Umur } & : \text { 42 Tahun } \\ \text { Agama } & : \text { Budha } \\ \text { Status } & : \text { Lajang } \\ \text { Tanggal pengkajian } & : \text { 05 Maret 2021 } \\ \text { Informant } & : \text { Status pasien dan komunikasi dengan pasien. }\end{array}$

\subsection{Alasan Masuk Yayasan Pemenang Jiwa}

Alasan pasien masuk yayasan pemenangan jiwa dikarenakan pasien mengatakan pasien sering dimarahi dan di pikuli oleh saudara laki-laki pasien. Pasien mendapat bekas luka diare lutut dan pernah menarima pukulan keras di area kepala. Sehingga keluarga pasien memutuskan untuk mengantar pasien ke Yayasan pemenang jiwa.

\subsection{Faktor Predisposisi}

Pasien sebelumnya pernah mengalami gangguan jiwa \pm 10 tahun yang lalu dan pulang kerumah dalam keadaan tenang. Dirumah pasien tidak rutin minum obat, tidak mau kontrol ke RSJ sehingga timbul gejala-gejala seperti diatas. Keluarga pasien tidak ada yang pernah mengalami gangguan jiwa. Masalah Keperawatan: isolasi sosial

\subsection{Fisik}

Pasien memiliki keluhan fisik diarea kepala dikarnakan pasien memiliki diagnose medis : EPILEPSI, saat dilakukan pemeriksaan tanda-tanda vital, didapatkan hasil TD : 110/80 mmHg ; $\mathrm{N}: 80 \mathrm{x} / \mathrm{i}$; S : 36,5 C ; : 20x/i. Pasien memiliki tinggi badan $169 \mathrm{~cm}$ dan berat badan $62 \mathrm{Kg}$. 


\subsection{Psikososial}

\subsubsection{Genogram}

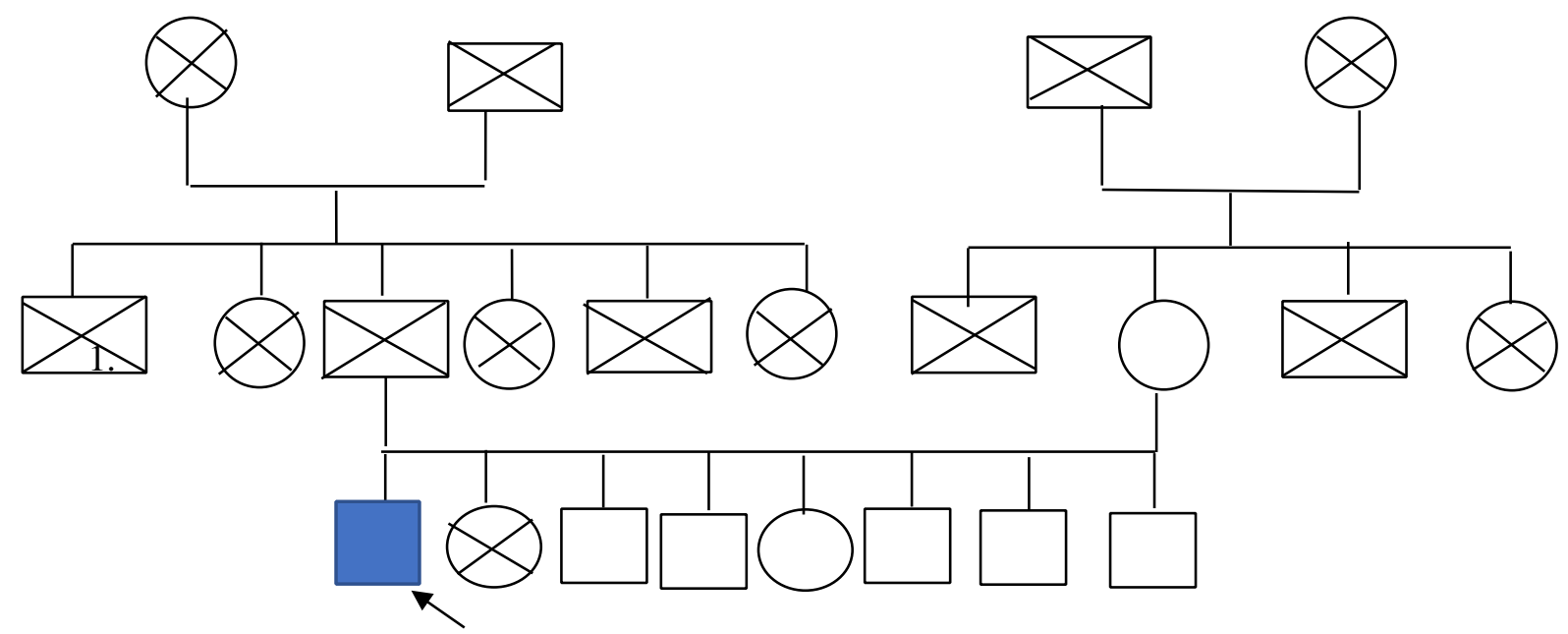

Penjelasan :

Pasien anak pertama dari 8 bersaudara, pasien berinisial Tn A, pasien memiliki ibu sedangkan ayah pasien sudah meninggal dunia dan saat usia pasien 10 tahun. Tn. A belum menikah. Keterangan :

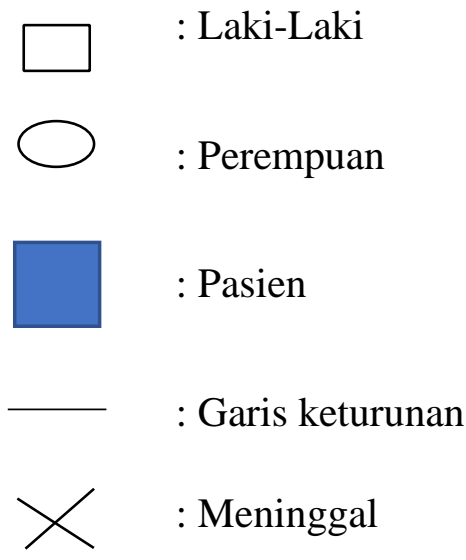

\subsubsection{Konsep diri}

a. Gambaran diri : Tidak ada kecacatan

b. Identitas : Pasien anak ke 1 dari 8 bersaudara, pasien SD

c. Peran : Pasien berperan sebagai anak dan masih lajang, pasien sebelunya tinggal bersama keluarganya sebelum ayahnya meninggal dunia. 
d. Ideal diri : Pasien merasa malu karena di antarkan ke yayasan pemenangan jiwa tersebut

e. Harga diri : Pasien merasa apakah dirinya tidak dianggap oleh saudara nya lagi semenjak orang tua nya meninggal dunia, karena dirinya di tempatkan jauh dari rumah

Masalah keperawatan: Gangguan konsep diri : Harga diri rendah

\subsubsection{Hubungan sosial}

Pasien mengganggap bahwa keluarganya adalah orang yang sangat berarti dalam hidupnya kecuali saudara laki-laki pasien, ayahnya sudah meninggal dunia keluarga yang paling berharga adalah kakaknya yang sebenarnya adalah adik dari pasien yang sering di panggil kakak sama adik ke dua pasien. Pasien selalu mengikuti kegiatan di yayasan tersebut. Pasien mengatakan tidak suka bergaul dengan teman-teman yang ada di yayasan pemenang jiwa, dia lebih suka menyendiri.

Masalah keperawatan: Isolasi sosial

\subsubsection{Spiritual}

1. Nilai dan Keyakinan :Pasien beragama kristen dan yakin dengan agamanya.

2. Kegiatan Ibadah :Ibadah 3 kali sehari. Yaitu pagi 2 kali, sekitar pukul 6 pagi dan pukul 10 pagi, selanjutnya jam 7 malam.

\subsubsection{Status Mental}

1. Penampilan

Pasien berpenampilan bersih, dan rapi

2. Pembicaraan

Pasien tidak mampu menjawab pertanyaan dengan jelas dan tidak dapat cepat memahami pertanyaan yang diberikan

3. Aktivitas Motorik

Pasien terlihat sedikit gelisah

4. Suasana perasaan 
Pasien merasa dibuang oleh keluarganya dan merasa minder dengan orang lain karena di rawat diyayasan pemenang jiwa

Masalah keperawatan : Harga Diri Rendah

5. Afek

Afek pasien labil, dan sering menunduk

Masalah keperawatan :Isolasi sosial

6. Interaksi selama wawancara

Pasien kooperatif, tidak ada kontak mata pada lawan bicara, sering menunduk dan tidak banyak bicara.

7. Persepsi

pasien merasa tidak pernah dihargai

8. Proses Pikir

Pasien tidak mampu menjawab apa yang ditanya dengan baik.

9. Isi piker

Pasien tidak dapat mengontrol isi pikirnya, pasien mengalami gangguan isi pikir akibat epilepsi dan tidak ada waham.

10. Tingkat kesadaran

Pasien mengalami gangguan orientasi, pasien mengenali waktu, orang dan tempat sesaat.

11. Memori

Pasien tidak mampu menceritakan kejadian di masa lalu

12. Tingkat konsentrasi berhitung

Pasien mampu berkonsentrasi dalam perhitungan sederhana tanpa bantuan orang lain.

13. Kemampuan penilaian

Pasien dapat membedakan hal yang baik dan yang buruk.

14. Daya tilik diri

Pasien tidak mengingkari penyakit yang diderita, pasien mengetahui bahwa dia sering marah. 


\subsection{Mekanisme Koping}

Pasien mengalami mekanisme koping adaptif yaitu pasien dapat berbicara baik dengan orang lain.

\subsection{Masalah Psikososial Dan Lingkungan}

Masalah dengan dukungan kelompok, spesifik : Pasien megatakan dukungan psikososial dan lingkungan di yayasan sangat baik, hanya saja dia lebih suka menyendiri.

Masalah Keperawatan : Isolasi sosial

\subsection{Pengetahuan Kurang Tentang}

Pasien tidak mengetahui tentang gangguan jiwa yang di alaminya, pasien mengatakan jika sedang ada waktu luang pasien memberihkan halaman dengan memotong rumput.

Masalah Keperawatan : Isolasi sosial.

\subsection{Aspek Medis}

Diagnosa Medik :
a. Isolasi sosial
b. Harga Diri Rendah

Terapi Medik : Pemberian/minum obat kepada pasien secara teratur.

a. Risperidon (RSP) tablet $2 \mathrm{mg} 2 \times 1$.

b. Klozapin $25 \mathrm{mg} 2 \mathrm{x} 1$ 


\subsection{Analisis Data}

\begin{tabular}{|c|c|c|}
\hline No & Data & Masalah Keperawatan \\
\hline 1 & $\begin{array}{l}\text { Subjektif: } \\
\text { Pasien mengatakan pernah menerima } \\
\text { tindak kekerasan dari saudara laki-laki } \\
\text { pasien } \\
\text { Objektif: } \\
\text { Pasien tampak tidak dapat memandang } \\
\text { orang lain dan sering menunduk }\end{array}$ & Isolasi Sosial \\
\hline 2. & $\begin{array}{l}\text { Subjektif: } \\
\text { Pasien mengatakan dibuang oleh } \\
\text { keluarganya dan merasa minder dengan } \\
\text { orang lain karena di rawat diyayasan } \\
\text { pemenang jiwa } \\
\text { Objektif : } \\
\text { Pasien tampak malu dan gelisah, dan } \\
\text { tampak sedih saat di kaji }\end{array}$ & $\begin{array}{l}\text { Gangguan Konsep Diri } \\
\text { : Harga diri rendah }\end{array}$ \\
\hline
\end{tabular}

\subsection{Pohon Masalah}

Isolasi sosial: menarik diri

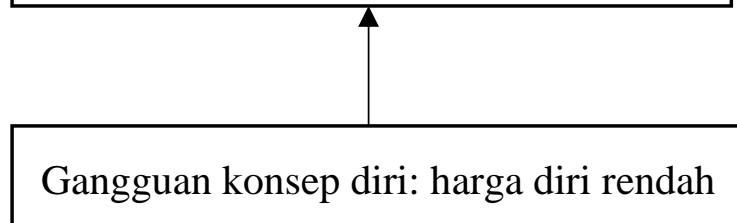




\subsection{Diagnosa Keperawatan Prioritas}

Isolasi sosial: menarik diri

\subsection{Intervensi Keperawatan}

\begin{tabular}{|c|c|c|c|}
\hline $\begin{array}{c}\text { Diagnosa } \\
\text { Keperawatan }\end{array}$ & Tujuan & Hasil & \\
\hline $\begin{array}{l}\text { Menarik diri : } \\
\text { Isolasi Sosial }\end{array}$ & $\begin{array}{c}\text { Klien } \\
\text { dapat } \\
\text { membina } \\
\text { hubungan } \\
\text { saling } \\
\text { percaya }\end{array}$ & 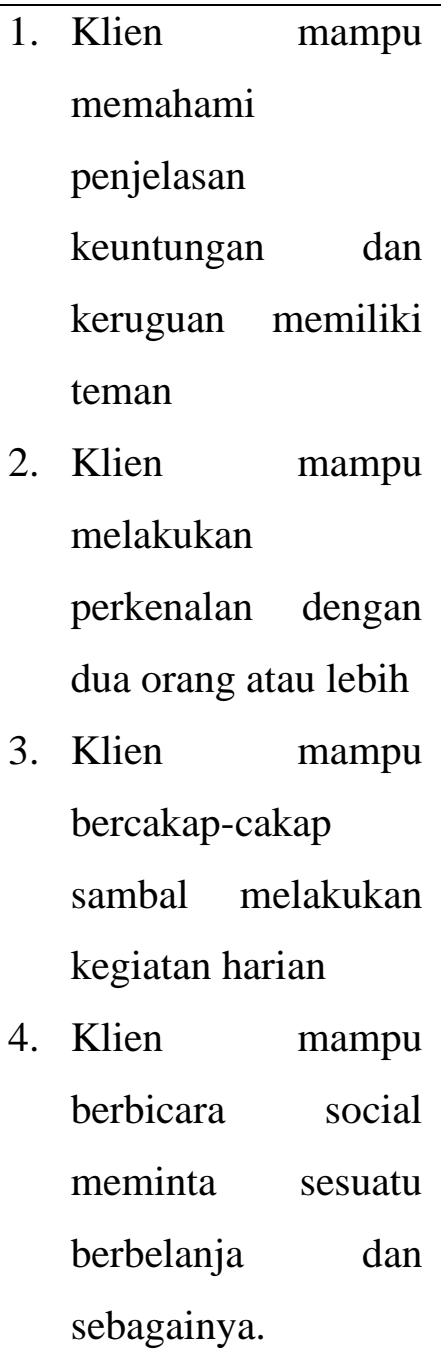 & $\begin{array}{l}\text { SP1: } \\
\text { Menjelasan keuntungan dan } \\
\text { keruguan memiliki teman } \\
\text { SP 2: } \\
\text { Melatih klien berkenalan } \\
\text { dengan dua orang atau lebih } \\
\text { SP 3: } \\
\text { Melatih bercakap-cakap } \\
\text { sambal melakukan kegiatan } \\
\text { harian } \\
\text { SP 4: } \\
\text { Melatih berbicara social } \\
\text { meminta sesuatu berbelanja } \\
\text { dan sebagainya. }\end{array}$ \\
\hline $\begin{array}{l}\text { Gangguan } \\
\text { konsep diri : } \\
\text { harga diri } \\
\text { rendah }\end{array}$ & $\begin{array}{l}\text { Klien } \\
\text { dapat } \\
\text { membina } \\
\text { hubungan } \\
\text { saling } \\
\text { percaya }\end{array}$ & $\begin{array}{l}\text { 1. Klien mampu } \\
\text { mengidentifikasi } \\
\text { kemampuan dan } \\
\text { aspek positif yang } \\
\text { dimiliki } \\
\text { 2. Klien mampu } \\
\text { menilai kemampuan }\end{array}$ & $\begin{array}{l}\text { SP 1: Mengidentifikasi } \\
\text { kemampuan dan aspek } \\
\text { positif yang dimiliki }\end{array}$ \\
\hline
\end{tabular}




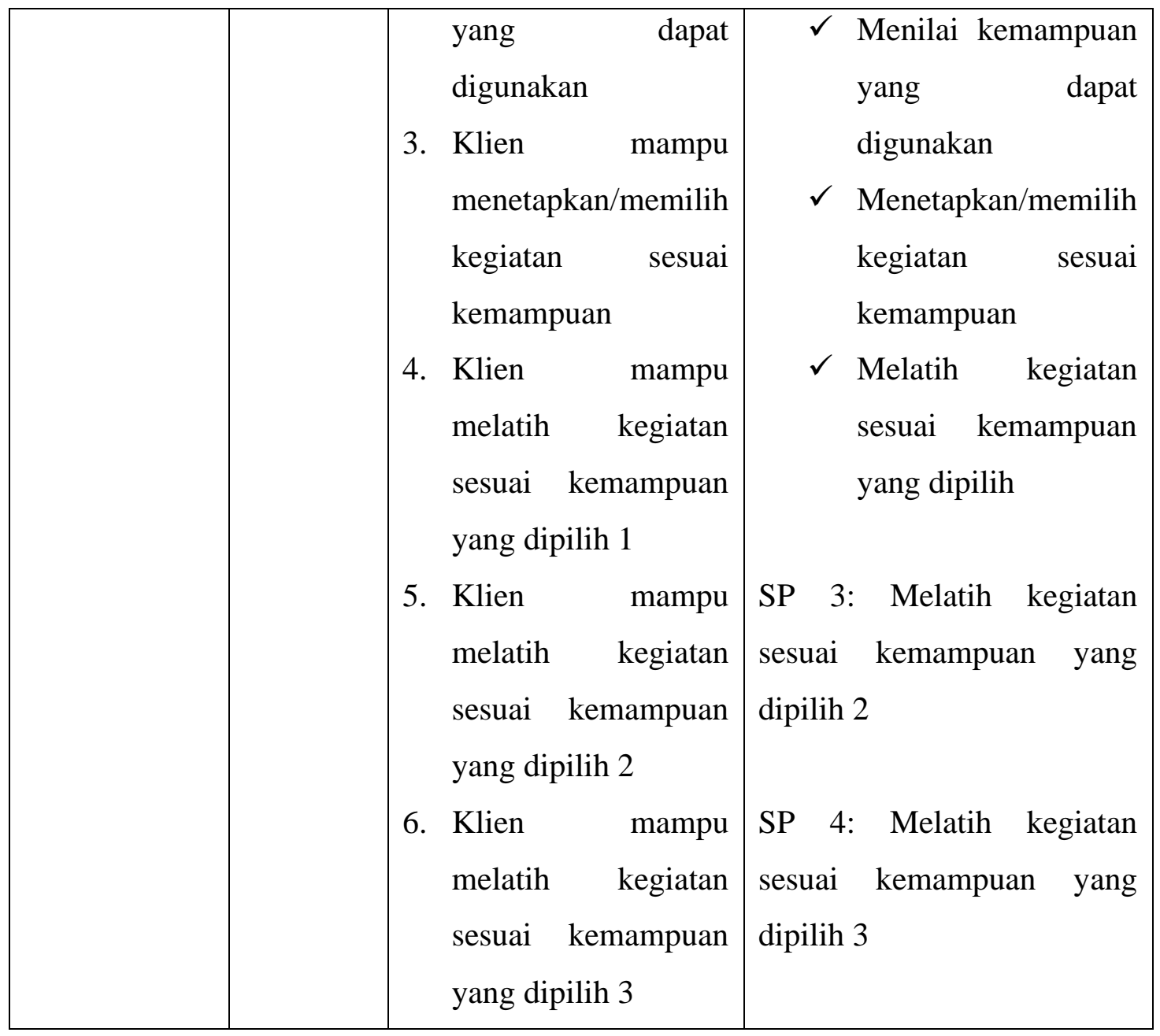




\subsection{Implementasi}

\begin{tabular}{|c|c|c|}
\hline Hari/tgl & Implementasi & Evaluasi \\
\hline $\begin{array}{l}\text { Selasa, } 09 \\
\text { Maret } 2021\end{array}$ & 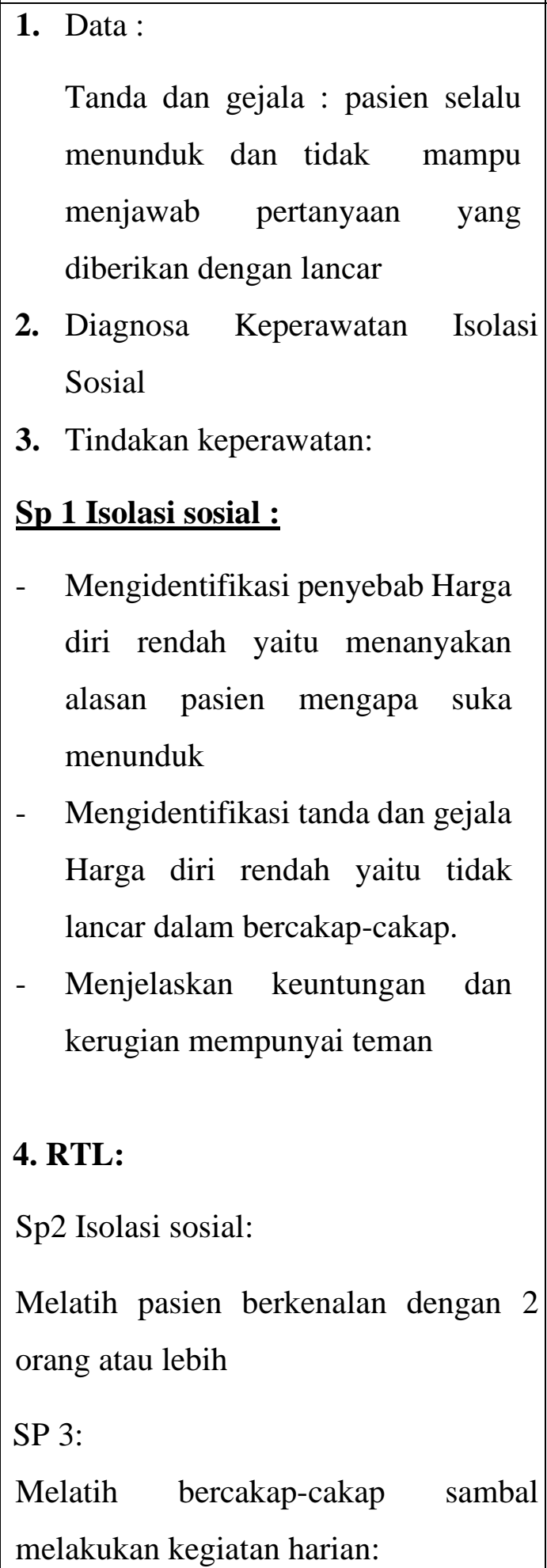 & 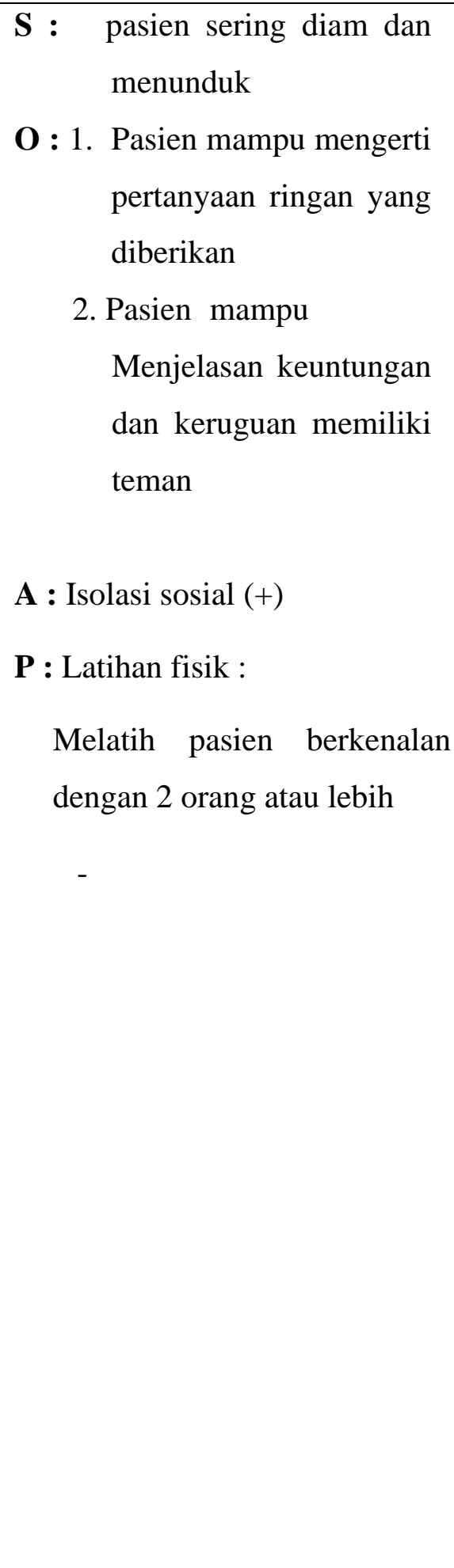 \\
\hline
\end{tabular}




\begin{tabular}{|c|c|c|}
\hline $\begin{array}{l}\text { Kamis , } 11 \\
\text { naret } 2021 . \\
11.30 \text { WIB. }\end{array}$ & $\begin{array}{l}\text { Data : } \\
\text { Tanda dan gejala : pasien selalu } \\
\text { menunduk dan tidak mampu } \\
\text { menjawab pertanyaan yang } \\
\quad \text { diberikan dengan lancar } \\
\text { Diagnosa Keperawatan Isolasi Sosial } \\
\text { Isolasi Sosial } \\
\text { Tindakan keperawatan: } \\
\text { SP 2: } \\
\text { Melatih klien berkenalan dengan dua } \\
\text { orang atau lebih } \\
\text { SP 3: } \\
\text { Melatih } \quad \text { bercakap-cakap sambal } \\
\text { melakukan kegiatan harian: } \\
\text { RTL: } \\
\text { SP 4: } \\
\text { Melatih kegiatan sesuai kemampuan } \\
\text { yang dipilih } 3\end{array}$ & $\begin{array}{l}\text { A : Isolasi Sosial (+) } \\
\text { P : } \\
\text { - } \text { Latihan berkenalan } \\
\text { dengan dua orang atau } \\
\text { lebih 1x sehari } \\
\text { - } \text { Latihan komunikasi } \\
\text { secara verbal } \\
\text { asertif/bicara baik-baik } \\
\text { 3x/ hari. }\end{array}$ \\
\hline
\end{tabular}




\begin{tabular}{|c|c|c|}
\hline $\begin{array}{l}\text { Selasa , } 16 \\
\text { maret } 2021 . \\
10.30 \mathrm{Wib} .\end{array}$ & $\begin{array}{l}\text { Data : } \\
\text { Tanda dan gejala : pasien selalu } \\
\text { menunduk dan tidak mampu } \\
\text { menjawab pertanyaan yang } \\
\text { diberikan dengan lancar } \\
\text { Diagnosa Keperawatan Isolasi Sosial } \\
\text { Isolasi Sosial } \\
\text { Tindakan keperawatan: } \\
\text { SP 3: } \\
\text { Melatih bercakap-cakap sambal } \\
\text { melakukan kegiatan harian: } \\
\text { SP 4: } \\
\text { Melatih kegiatan sesuai kemampuan } \\
\text { yang dipilih } 3 \\
\text { Rtl: } \\
\text { Pemberian Sp Harga Diri Rendah } \\
\text { Mengidentifikasi kemampuan dan } \\
\text { aspek positif yang dimiliki pasien }\end{array}$ & 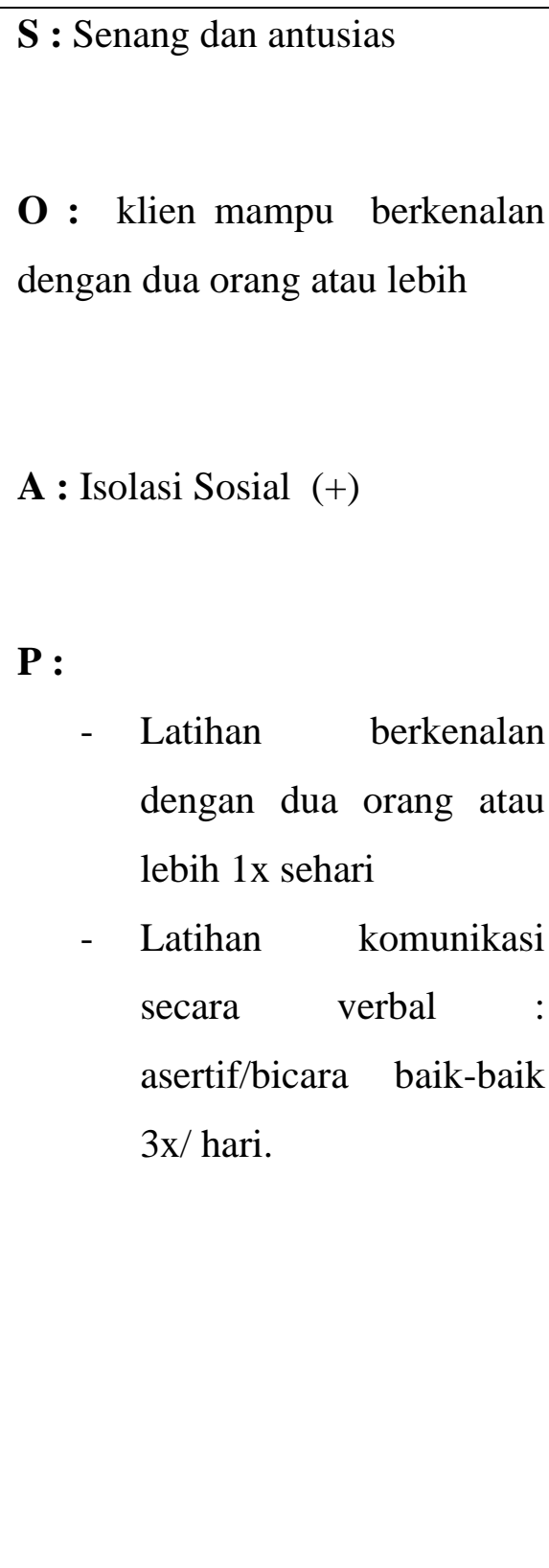 \\
\hline
\end{tabular}




\begin{tabular}{|c|c|c|}
\hline $\begin{array}{l}\text { Jumat, } \\
\text { maret } 2021 . \\
11.30 \mathrm{Wib} .\end{array}$ & $\begin{array}{l}\text { Data } \\
\text { - Klien tampak murung } \\
\text { - Berbicara hanya ketika ditanya } \\
\text { - Nada bicara pelan } \\
\text { Diagnosa Keperawatan } \\
\text { Gangguan konsep diri : Harga Diri } \\
\text { Rendah } \\
\text { Tindakan Keperawatan } \\
\text { Sp1 } \\
\text { Mengidentifikasi kemampuan dan } \\
\text { aspek positif yang dimiliki pasien } \\
\text { RTL } \\
\text { Sp } 2 \text { : - menilai kemampuan yang dapat } \\
\text { digunakan } \\
\text { - Menetapkan/memilih kegiatan } \\
\text { Sp3 : Mesuai kemampuan } \\
\text { kemampuan yang dipilih } 2 \\
\text { - Melatih kegiatan sesuai } \\
\text { - }\end{array}$ & $\begin{array}{l}\text { S : Senang: } \\
\text { - } \text { Pasien mampu mengenali } \\
\text { Mengidentifikasi } \\
\text { kemampuan dan aspek } \\
\text { positif yang dimiliki } \\
\text { pasien } \\
\text { A : harga diri rendah (+) } \\
\text { P : Latihan mengidentifikasi } \\
\text { kemampuan dan aspek positif } \\
\text { yang dimiliki pasien harga diri } \\
\text { rendah 3x/hari }\end{array}$ \\
\hline
\end{tabular}




\begin{tabular}{|c|c|c|}
\hline $\begin{array}{l}\text { Selasa, } 22 \\
\text { maret } 2021 . \\
11.30 \mathrm{Wib}\end{array}$ & 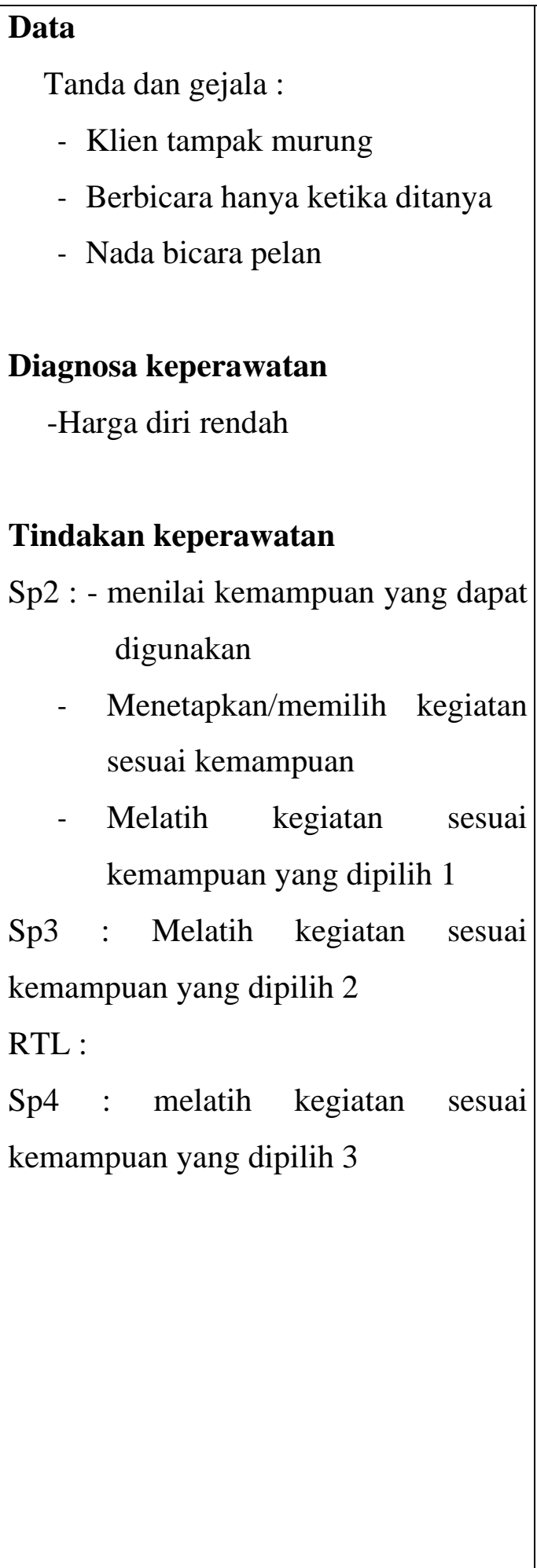 & 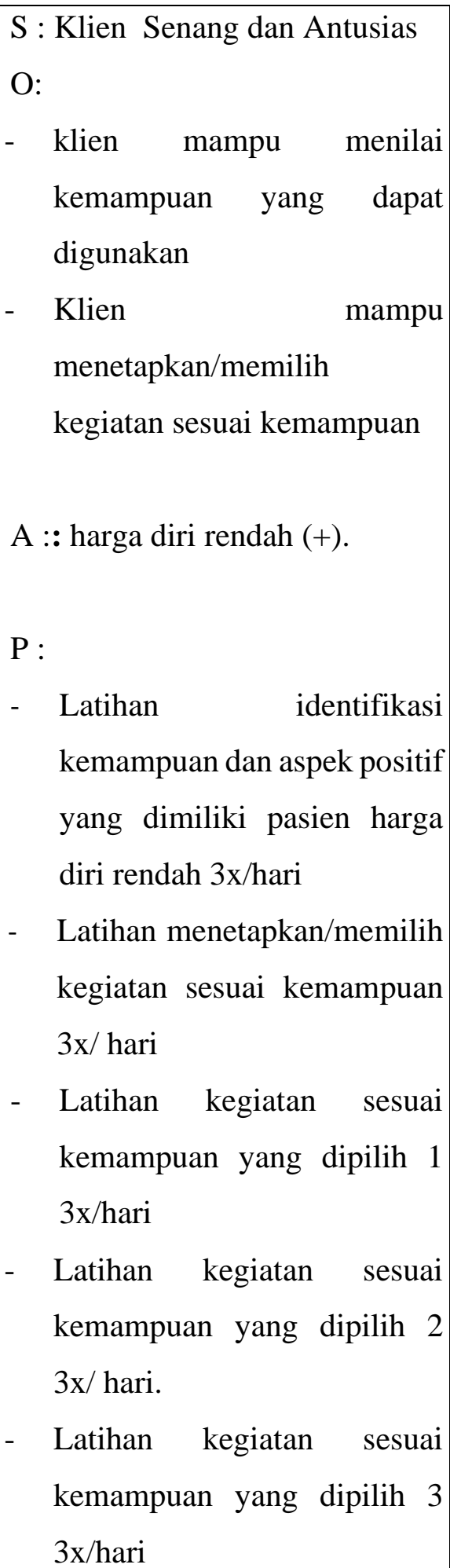 \\
\hline
\end{tabular}




\begin{tabular}{|c|c|c|}
\hline $\begin{array}{l}\text { Selasa, } 22 \\
\text { maret } 2021 . \\
11.30 \mathrm{Wib}\end{array}$ & $\begin{array}{l}\text { Data } \\
\text { Tanda dan gejala : } \\
\text { - Klien tampak murung } \\
\text { - Berbicara hanya ketika ditanya } \\
\text { - Nada bicara pelan } \\
\text { Diagnosa keperawatan } \\
\text {-Harga diri rendah } \\
\text { Tindakan keperawatan } \\
\quad \text { Sp4 : melatih kegiatan sesuai } \\
\text { kemampuan yang dipilih } 3\end{array}$ & 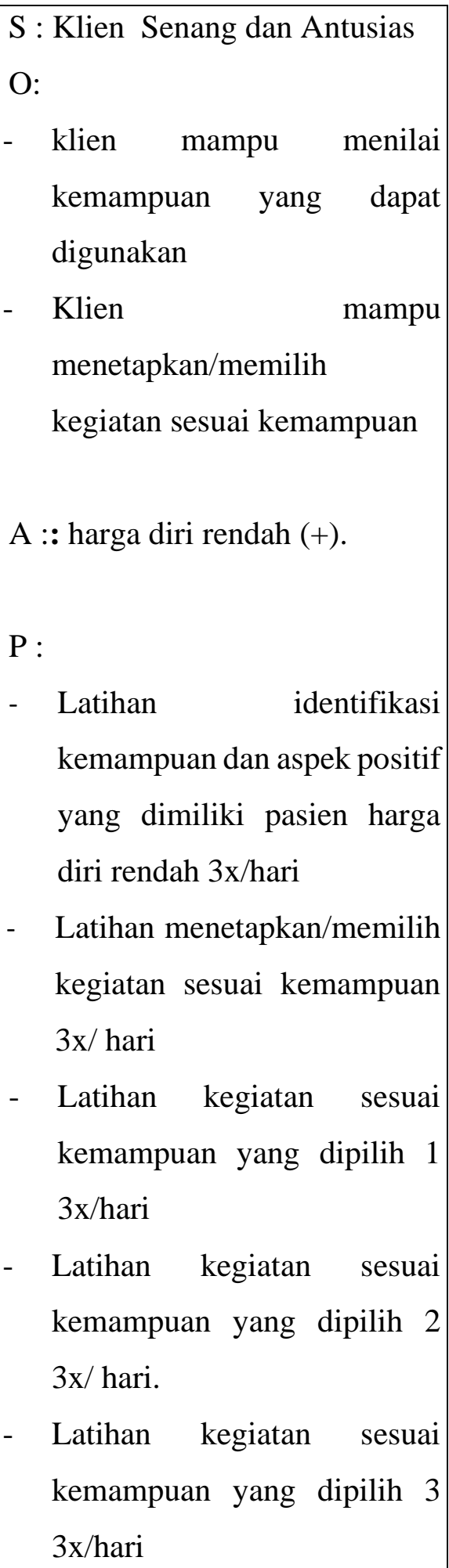 \\
\hline
\end{tabular}




\section{BAB 4 \\ PEMBAHASAN}

Setelah mahasiwa melaksanakan asuhan keperawatan kepada Tn. A dengan masalah isolasi sosial di Yayasan Pemenang Jiwa Sumatera, maka mahasiswa pada BAB ini akan membahas kesenjangan antara teoritis dan tinjauan kasus. Pembahasan dimulai melalui tahapan prosess keperawatan yaitu pengkajian, diagnosa keperawatan, perencanaan, pelaksanaan dan evalusi.

\subsection{Tahap Pengkajian}

Pada pembahasan ini diuraikan tentang hasil pelaksanaan tindakan keperawatan dengan pemberian terapi generalis pada klien Isolasi Sosial. Pembahasan menyangkut analisis hasil penerapan terapi generalis terhadap masalah keperawatan Isolasi Sosial. Tindakan keperawatan didasarkan pada pengkajian dan diagnosis keperawatan yang terdiri dari tindakan generalis yang dijabarkan sebagai berikut.

Tahap pengkajian pada klien Isolasi Sosial dilakukan interaksi perawat-klien melalui komunikasi terapeutik untuk mengumpulkan data dan informasi tentang status kesehatan klien. Pada tahap ini terjadi proses interaksi manusia, komunikasi, transaksi dengan peran yang ada pada perawat sebagaimana konsep Peplau tentang manusia yang bisa dipengaruhi dengan adanya proses interpersonal.

Selama pengkajian dilakukan pengumpulan data dari beberapa sumber, yaitu dari pasien dan tenaga kesehatan di ruangan. Penulis mendapat sedikit kesulitan dalam menyimpulkan data karena keluarga pasien jarang mengunjungi pasien di yayasan. Maka penulis melakukan pendekatan kepada pasien melalui komunikasi terapeutik yang lebih terbuka membantu pasien untuk memecahkan perasaannya dan juga melakukan observasi kepada pasien.

Adapun upaya tersebut yaitu:

1. Melakukan pendekatan dan membina hubungan saling percaya diri pada klien agar klien lebih terbuka dan lebih percaya dengan menggunakan perasaan.

2. Mengadakan pengkajian klien dengan wawancara

3. Mengadakan pengkajian dengan cara berbicara dengan pasien dan petugas yayasan. 
Dalam pengkajian ini, penulis tidak menemukan kesenjangan karena ditemukan hal sama seperti pada tinjauan teoritis. Pada kasus Ny.W, Banyak berdiam diri di kamar, klien menyendiri dan tidak mau berinteraksi dengan orang yang terdekat, klien tampak sedih, ekspresi datar dan dangkal, kontak mata kurang, Apatis (acuh terhadap lingkungan), Ekpresi wajah kurang berseri

Tindakan keperawatan terapi generalis yang dilakukan pada Ny.w adalah strategi pertemuan pertama sampai pertemuan ketiga. Strategi pertemuan pertama meliputi Menggajarkan Keuntungan Dan Kerugian Mempunyai Teman dan melatih pasien untuk berkenalan dengan 2 orang atau lebih. Strategi pertemuan kedua yang dilakukan pada Ny.S meliputi melatih cara mengendalikan dengan bercakap-cakap kepada orang lain sambil beraktifitas berbelanja tau meminta tolong, , melakukan kegiatan positif seperti mengambar, melipat kain. menyusun jadwal kegiatan bersama-sama dengan klien

\subsection{Tahap Perencanaan}

Perencanaan dalam proses keperawatan lebih di kenal dengan asuhan keperawatan yang merupakan tahap selanjutnya setelah pengkajian dan penentuan diagnosa keperawatan. Pada tahap perencanaan mahasiswa menyusun rencana tindakan keperawatan Harga diri rendah, dan Harga Diri Rendah. Pada tahap ini antara tinjauan teroritis dan tinjauan kasus tidak ada kesenjangan sehingga mahasiswa dapat melaksanakan tindakan seoptimal mungkin di dukung dengan seringnya bimbingan dengan pembimbing. Secara teoritis digunakan secara strategi pertemuan sesuai dengan diagnosa keperawatan yang muncul saat pengkajian. Adapun upaya yang digunakan mahasiswa ialah :

\section{Isolasi Sosial}

1. Menjelasan keuntungan dan keruguan memiliki teman

2. Melatih klien berkenalan dengan dua orang atau lebih

3. Melatih bercakap-cakap sambal melakukan kegiatan harian

4. Melatih berbicara social meminta sesuatu berbelanja dan sebagainya. 
Harga diri rendah

1. Mengidentifikasi kemampuan dan aspek positif yang dimiliki pasien

a. Menilai kemampuan yang dapat digunakan

b. Menetapkan atau memilih kegiatan sesuai kemampuan

c. Melatih kegiatan sesuai kemampuan yang dipilih 1

2. Melatih kegiatan sesuai kemampuan yang dipilih 2

3. Melatih kegiatan sesuai kemampuan yang dipilih 3

4. Mengevalusi jadwal kegiatan harian pasien.

\subsection{Tahap Implementasi}

Pada tahap implementasi mahasiswa mengatasi masalah keperawatan dengan diagnosa keperawatan Harga diri rendah/Perilaku Kekerasan karena masalah utama yang dialami pasien. Pada diagnosa keperawatan Harga diri rendah/Perilaku Kekerasan strategi pertemuan ialah mengidentifikasi perilaku kekerasan, mengontrol perilaku kekerasan, dan cara tarik nafas dalam dan pukul bantal kasur. Strategi pertemuan yang kedua ialah anjurkan minum obat secara teratur, strategi pertemuan ketiga ialah latihan cara komunikasi secara verbal atau bicara baik-baik. dan strategi terakhir pertemuan keempat yaitu spiritual (Hasannah, 2019). .

\subsection{Tahap Evaluasi}

Pada tinjauan kasus evaluasi yang dihasilkan adalah :

1. Pasien sudah dapat memahami keuntungan dan keruguan memiliki teman

2. Pasien dapat berkenalan dengan dua orang atau lebih

3. Pasien dapat bercakap-cakap sambil melakukan kegiatan harian

4. Pasien dapat berbicara social meminta sesuatu berbelanja dan sebagainya. 


\section{BAB 5 \\ PENUTUP}

\subsection{Kesimpulan}

Berdasarkan uraian pada pembahasan di atas, maka penulis dapat disimpulkan bahwa:

1. Pengkajian dilakukan secara langsung pada klien dan juga dengan menjadikan status klien sebagai sumber informasi yang dapat mendukung data-data pengkajian. Selama proses pengkajian, perawat mengunakan komunikasi terapeutik serta membina hubungan saling percaya antara perawat-klien. Pada kasus Tn. A diperoleh bahwa klien mengalami gejala-gejala Isolasi Sosial seperti tidak mau berinteraksi dengan orang lain, sering menyendiri, tidak mau diajak berbicara, kurrang kontak mata saat berbicara. Faktor predisposisi pada Tn. A yaitu pernah mengalami kejadian ditinggal oleh anak dan suaminya.

2. Diagnosa keperawatan yang muncul pada kasus Tn. A sebanyak: isolasi sosial dan harga diri rendah kronis .

3. Perencanaan dan implementasi keperawatan disesuaikan dengan strategi pertemuan pada pasien Isolasi sosial.

4. Evaluasi dperoleh bahwa terjadi peningkatan kemampuan klien dalam berinteraksi dengan orang lain.

\subsection{Saran}

1. Bagi Perawat

Diharapkan dapat meenrapkan komunikasi terapeutik dalam pelaksanaan strategi pertemuan 1-4 pada klien dengan isolasi sosial sehingga dapat mempercepat proses pemulihan klien.

2. Bagi Institusi Pendidikan

Dapat meningkatkan bimbingan klinik kepada mahasiswa profesi ners sehingga mahasiswa semakin ampu dalam elakukan asuhan keperawatan pada pasienpasien yang mengalami isolasi sosial.

3. Bagi Yayasan

Laporan ini diharapkan dapat menjadai acuan dan referensi dalam memberikan asuhan keperawatan pada klien dengan Isolasi Sosial. 


\section{DAFTAR PUSTAKA}

1. Anggit, M. A. (2021). Asuhan Keperawatan Jiwa Pada Pasien Dengan Resiko Perilaku Kekerasan. Universitas Kusuma Husada Surakarta.

2. Astuti, L. (2020). Studi Dokumentasi Isolasi Sosial Pada Pasien Dengan Skizofrenia. Akademi Keperawatan YKY Yogyakarta. http://repository.akperykyjogja.ac.id/id/eprint/295

3. Damanik, R. K., Pardede, J. A., \& Manalu, L. W. (2020). Terapi Kognitif Terhadap Kemampuan Interaksi Pasien Skizofrenia Dengan Isolasi Sosial. Jurnal Ilmu Keperawatan dan Kebidanan, 11(2), 226-235. DOI: http://dx.doi.org/10.26751/jikk.v11i2.822

4. Dermawan, D. (2013). Keperawatan Jiwa: Konsep dan Kerangka Kerja/Asuhan Keperawatan Jiwa. Yogyakarta: Goysen Publishing. http://dx.doi.org/10.26751/jikk.v11i2.822

5. Hasannah, S. U. (2019). Asuhan Keperawatan Jiwa pada Pasien Dengan Risiko Perilaku Kekerasan (Doctoral dissertation, STIKes Kusuma Husada Surakarta). http://eprints.ukh.ac.id/id/eprint/41

6. Kemenkes RI. (2019). Riset Kesehatan Dasar, RISKESDAS. Jakarta: KemenkesRI.https://databoks.katadata.co.id/datapublish/2019/10/08/persebaranprevalensi-skizofreniapsikosis-di-indonesia\#

7. Pitayanti, A., \& Hartono, A. (2020). Sosialisasi Penyakit Skizofrenia Dalam Rangka Mengurangi Stigma Negatif Warga di Desa Tambakmas KebonsariMadiun. Journal of Community Engagement in Health,3(2), 300-303. https://jceh.org/index.php/JCEH/article/view/83/78

8. Nursito, E. H. (2012). Asuhan Keperawatan Jiwa Pada Tn. S Dengan Gangguan Isolasi Sosial: Menarik Diri Di Ruang Maespati Rumah Sakit Jiwa Daerah Surakarta (Doctoral dissertation, Universitas Muhammadiyah Surakarta). http://eprints.ums.ac.id/id/eprint/21134

9. Pardede, J. A. (2018). Pelaksanaan Tugas Keluarga Dengan Frekuensi Kekambuhan Pasien Skizofrenia Dengan Masalah Isolasi Sosial. Jurnal Keperawatan Jiwa, 6(2).

10. Pardede, J. A., \& Laia, B. (2020). Decreasing Symptoms of Risk of Violent Behavior in Schizophrenia Patients Through Group Activity Therapy. Jurnal Ilmu Keperawatan Jiwa, 3 (3), 291-300. http://journal.ppnijateng.org/index.php/jikj/article/view/621/338

11. Pardede, J. A., Hamid, A. Y. S., \& Putri, Y. S. E. (2020). Application of Social Skill Training using Hildegard Peplau Theory Approach to Reducing Symptoms and the Capability of Social Isolation Patients. Jurnal Keperawatan, 12(3), 327340. https://doi.org/10.32583/keperawatan.v12i3.782

12. Pitayanti, A., \& Hartono, A. (2020). Sosialisasi Penyakit Skizofrenia Dalam 
Rangka Mengurangi Stigma Negatif Warga di Desa Tambakmas KebonsariMadiun. Journal of Community Engagement in Health,3(2), 300-303. https://doi.org/10.30994/jceh.v3i2.83

13. Purniawan, F. G. P. Asuhan Keperawatan Keluarga Tn. S dan Ny. W Yang Anggota Keluarganya Mengalami Skizofrenia Dengan Masalah Keperawatan Isolasi Sosial Di Wilayah Kerja Puskesmas Rogotrunan Lumajang Tahun 2018. http://repository.unej.ac.id/handle/123456789/87862

14. Quardona, Q., \& Agustina, M. (2018). Dukungan Emosional dan Instrumental dengan Interaksi Sosial pada Pasien Isolasi Sosial. Jurnal Ilmiah Ilmu Keperawatan Indonesia, 8(02), 429-435. https://doi.org/10.33221/jiiki.v8i02.319

15. Suerni, T., Keliat, B. A., \& CD, N. H. (2013). Penerapan Terapi Kognitif dan Psikoedukasi Keluarga pada Klien Harga Diri Rendah di Ruang Yudistira Rumah Sakit Dr. H. Marzoeki Mahdi Bogor Tahun 2013. Jurnal Keperawatan Jiwa, 1(2). https://doi.org/10.26714/jkj.1.2.2013.\%25p

16. Sukaesti, D. (2019). Sosial Skill Training Pada Klien Isolasi Sosial. Jurnal Keperawatan Jiwa, 6(1), 19-24. https://doi.org/10.26714/jkj.6.1.2018.19-24

17. Surakarta (Doctoral dissertation, Universitas Muhammadiyah Surakarta). http://eprints.ums.ac.id/id/eprint/21134

18. Suwarni, S., \& Rahayu, D. A. (2020). Peningkatan Kemampuan Interaksi Pada Pasien Isolasi Sosial Dengan Penerapan Terapi Aktivitas Kelompok Sosialisasi Sesi 1-3. Ners Muda, 1(1), 11-17. https://doi.org/10.26714/nm.v1i1.5482

19. Wandono, W. A., \& Arum Pratiwi, S. (2017). Upaya peningkatan Isolasi Sosia pada pasien depresi (Doctoral dissertation, Universitas Muhammadiyah Surakarta).http://eprints.ums.ac.id/id/eprint/52383

20. WHO, (2019). Schizophrenia. Retrieved from. https://www.who.int/newsroom/fact-sheets/\%20detail/schizophrenia

21. Yuswatiningsih, E., \& Rahmawati, I. M. H. (2020). Terapi Social Skill Training (SST) Untuk Klien Isolasi Sosial. E-Book Penerbit STIKes Majapahit, 1-129. http://ejournal.stikesmajapahit.ac.id/index.php/EBook/article/view/661/673 